\title{
ICT management in Latin America educational institutions. Between policies and innovation.
}

\author{
Patricia Avitia Carlos $^{a}$, Bernabé Rodríguez Tapia ${ }^{\mathrm{b}}$, Norma Candolfi Arballo \\ Universidad Autónoma de Baja California, Tijuana, México, ${ }^{a}$ patricia_avitia@uabc.edu.mx, \\ brodriguez.bernabe@uabc.edu.mx, cncandolfi@uabc.edu.mx
}

\begin{abstract}
The use of Information and Communication Technologies (ICT) in educational contexts has focused its greatest efforts on the acquisition and use of technology. This makes necessary a conceptual and methodological redesign of its use, one that integrates all the members of the organization and generate permanent changes in the culture of the organization (Salinas, 2005). The management of educational institutions is crucial to normalize experiences and provide references that can be integrated into environmental conditions. Despite this, educational management has been relegated to the studies of innovation in education supported by technology, with little systematized information in this regard (Sunkel, Trucco, \& Espejo, 2013). The present work uses bibliographic techniques to analyze the trends that have been followed in Latin America in terms of educational management for the adoption of ICT. The influence of public policy on the promotion of these programs is observed, as well as the need for a theoretical methodological support for the development of an integral management model, in which the technology component does not constitute a parallel item..
\end{abstract}

Keywords: Educational management, ICT policies, innovation.

\section{Introduction}

The notion of Information and Communication Technologies (ICT) as a relevant element within the innovation processes of organizations, including educational ones, is increasingly accepted (Cifuentes, 2016; 2016; Kozma, 2010). Likewise, the notion of ICT as an innovative element is reinforced by recent empirical studies of the OECD (2012), pointing to a positive relationship between adoption and use of ICT and the economic performance of its member countries at micro and macro levels. 
In its report on innovation in the knowledge economy, the OECD (2004) points to ICT as a driver of innovation along with three other major drivers: scientific knowledge, collaboration between user-makers and modular structures. Thus, the creation of user networks and the flow of shared knowledge are valued as articulators of innovations with the potential to break into the entire system and not to only be absorbed by their current practices.

In the education field, ICTs have been identified within public policies as elements of innovation with expectations of knowledge potentialization and democratization of education, producers of development with equity (Lugo \& Brito, 2015; Represas, 2015). These expectations have risen ICT initiatives in almost all countries, with emphasis on the provision of infrastructure and improvement in access indicators.

Nevertheless, results from ICT incorporation in education do not show the expected scope and effectiveness; suggesting that they have not revolutionized but reinforced existing teaching methods, curricula and educational goals (Watson, 2006; Torres, 2010). In other words, they have been assimilated by current systems without having generated the anticipated disruptive effect. Similarly, UNESCO (2011) points out that policies have the capacity to add value to the educational processes and system results; as long as they are considered a systemic change. In this systemic perspective policies are capable of promoting innovations based on technology. Yet, innovations could occur throughout the system and still not change it, if their objectives, practices and structures remain unchanged.

Cifuentes (2016) considers that future research on ICT should consider the area of implementation (execution) of education policy as a key part of the analysis of contemporary educational policies in the Latin American context. Is in the execution where we find the reinterpretation of policy that is carried out within the organizations to integrated it into the existing structure and processes. Thus, it is necessary a methodological redesign in relation to the adoption of technology, to integrate all the actors and generate permanent changes in the organization (Salinas, 2005).

An understanding of the integration of ICT in teaching-learning processes reveals that there is a close relationship with politics, under which the academic, administrative and organizational aspects are intertwined (Cifuentes, 2016). This internal management of educational institutions combines quality assurance systems and accountability practices of both academic and administrative personnel; including discourses of efficiency in the practice of public management. Strategic plans increase success in the integration of ICT in educational contexts (Cifuentes \& Vanderlinde, 2015). Despite this, the influence of ICT management models in schools as part of the implementation of public education policies has not received enough attention and has been relegated from studies of innovation 
supported by technology in education. As a result, there is little systematized information about it (Sunkel, 2013; Cifuentes, 2016).

Management can be defined from different perspectives. If observed from the organization actors interactions, it can be understood as "the ability to articulate mental representations of the members of an organization" (Casassus, 2000, p.4). In order to observe the implementation of public policies, we consider the ICT management in education from the paradigm of the mobilization of resources (material, human and social).

The objective of this work was to identify representative ICT integration programs in educational activities presented in recent decades in Latin America, as part of the interpretation and adaptation of public policies to the particular context. The aim is to emphasize the mechanisms established by the actors to assume the strategic planning of innovation from the day-to-day management of the school. To meet this objective, an exploratory study based on bibliographic techniques was proposed. The literature review methodology uses both public documents from official government sites and supranational organizations, as well as articles in scientific databases that account for regional experiences in the field and meet the criteria of thematic and temporal relevance.

Results from the study provide a descriptive framework for the recent implementation of ICT educational public policy on several Latin American countries. It presents the relationship between strategies and management that have been developed in each particular case for the adoption of technological resources and their adaptation to the contextual characteristics. This review contributes both to the analytical reflection of the processes of adoption of innovations, and to establishing comparisons of the management models used in the educational field to interpret and execute public policy from a preexisting organizational structure.

\section{Methodology}

In order to meet the established research objective, an exploratory study based on bibliographic techniques was developed. According to Chong (2007, p.187), a documentary research "is the methodical and formal process that facilitates and supports the agile and systematized access to the product of scientific research, reported in documentary sources". Its importance lies in that it "leads to the collection of information, systematically, analytically, synthetically and critically".

Documents with the following characteristics were included in the review: 
- Bibliographic database; including peer reviewed articles and books published in Spanish or English from year 2000 to date .

- Databases of international organizations for education and economic development: UNICEF, OECD, CEPAL \& SITEAL.

- Electronic pages of government agencies; Colombia, Mexico \& Argentina.

In the end, more than 70 articles from scientific journals, 4 databases and 3 government websites were analyzed. For each coincidence, priority was given to the existence of an exposition of the policies that went beyond the discourse analysis to focus on the experiences and their results; preferably from the actors vision.

\section{Results}

Countries in Latin America are part of a heterogeneous region, where great socioeconomic inequalities are yet present, despite most of them having a democratic process and a growing economy in decades (Lugo \& Brito, 2015). According to the OECD, governments consider ICT to be an important platform for research and innovation in all sectors. Consequently, its main associated areas of interest are: penetration of bandwidth, research and development in ICT, financing for innovative entrepreneurship, and diffusion of technology in business. Particularly with regard to ICT, the priorities during 2012 of the member countries of the OECD were: ICT skills and employment, online government, as well as the security of information systems and networks (OECD, 2012).

Still, schools in less developed countries, such as those in South America, face more barriers to the use of ICT in addition to the primary represented by accessibility. Some range from access to computers, lack of software, technical and administrative support, teacher training, internet access and, in some cases, even lack of electricity in some areas (Kozma, 2010).

Hence, about $44 \%$ of developing countries have developed national plans for the growth of the ICT sector and another $20 \%$ are in the process of developing them. Although a large number of countries are reported with plans to accelerate infrastructure, more specifically the adoption of bandwidth, there is great diversity among them in terms of objectives and policies. Remarkable is also the fact that in many of the programs there is a lack of theoretical bases to carry out the evaluation of the effectiveness of such ICT policies (Prashant, 2015). Some of the ICT programs settled in Latin America as part of the strategic development initiatives are shown in Table 1.1. This list does not intend to be exhaustive, 
but to account for the diversity of existing proposals in the region and, in some cases, even within the same country.

Table 1.1. Strategic programs in Latin America for the incorporation of ICT in education.

\begin{tabular}{|c|c|}
\hline \multirow{2}{*}{ Argentina } & Educ.ar \\
\hline & Programa Núcleos de Acceso al Conocimiento \\
\hline Bolivia & Una computadora por docente \\
\hline \multirow[t]{2}{*}{ Brasil } & Programa Nacional de Acesso ao Ensino Técnico e Emprego (Bronatec) \\
\hline & Programa Nacional de Formacã Continuada em Tecnologia Educacional (Integrated ProInfo) \\
\hline \multirow[t]{2}{*}{ Colombia } & Educa Digital Colombia $\mathbb{B}$ \\
\hline & Programa de Formación de Educadores CREA-TIC: Inspirar, Crear y Diseñar Aprendizajes con TIC \\
\hline \multirow[t]{2}{*}{ Costa Rica } & Plan Nacional de Tecnologías Móviles (PNTM), Tecne@prender \\
\hline & Programa Nacional de Informática Educativa (PRONIE MEP-FOD) \\
\hline Cuba & Joven Club de Computación y Electrónica (JCCE) \\
\hline \multirow[t]{2}{*}{ Chile } & Formación Docente para el Desarrollo de Competencias TIC \\
\hline & Tecnología en el Curriculum \\
\hline \multirow{2}{*}{$\begin{array}{l}\text { República } \\
\text { Dominicana }\end{array}$} & Agenda Digital \\
\hline & Programa Compumaestro 2.0 \\
\hline \multirow[t]{2}{*}{ Ecuador } & Agenda Educativa Digital \\
\hline & Plan de Acceso Universal y Alistamiento Digital \\
\hline \multirow[t]{2}{*}{ E1 Salvador } & Programa Creando Conocimiento \\
\hline & Programa "Cerrando la brecha del conocimiento" \\
\hline Guatemala & Estrategia para una Educación de Calidad para la Niñez y Juventud Guatemalteca \\
\hline Honduras & Agenda Digital de Honduras 2014-2018 \\
\hline \multirow[t]{2}{*}{ México } & Estrategia Digital Nacional \\
\hline & México conectado \\
\hline Nicaragua & Proyecto de Telecomunicaciones rurales \\
\hline \multirow[t]{2}{*}{ Panamá } & Aprende al Máximo \\
\hline & Para, Piensa, Conéctate \\
\hline \multirow[t]{2}{*}{ Paraguay } & Plan Director TIC \\
\hline & Alfabetización digital (Infocentros comunitarios) \\
\hline \multirow[t]{2}{*}{ Perú } & TIC para la educación pública \\
\hline & Plan de Desarrollo de la Sociedad de la Información en el Perú La Agenda Digital 2.0 \\
\hline \multirow[t]{2}{*}{ Uruguay } & Uruguay Digital \\
\hline & Plan Ceibal (Conectividad Educativa de Informática Básica para el Aprendizaje en Línea) \\
\hline Venezuela & Plan Nacional de Alfabetización y Formación Tecnológica \\
\hline
\end{tabular}

Source: SITEAL (2019)

In the case of Peru (Balarín, 2013) there is a lack of systematized official information to allow the analysis of the impact of ICT policies in recent years. Likewise, the alternation between two trends is reported: centralizing the management of ICT policies and mainstreaming at all levels and spheres. In counterpart, Colombia is an example of the development of an ICT policy with a strategic vision; addressing elements such as infrastructure, human capital development, improvement of teaching practices with technology and management and production of digital educational resources. Thus, through its PlanEsTIC program, higher education institutions were encouraged to develop, implement and evaluate their own plan (Cifuentes, 2016; Galvis, 2014). In this flexible way, the characteristics of the context and the culture of the organization could be considered within its own strategy of technological appropriation and policy execution. 
Argentina, for its part, has recognized both the financing difficulties involved in the obsolescence of ICT, as well as the importance of linking the public and private sectors in these initiatives. Its Connect Equality Program aims to go beyond the provision of infrastructure, to reorganize the actions of institutions in the same field; recognizing the importance of communication policies in educational management (Vacchieri, 2013). In the same case is Costa Rica, where ICT projects are developed in conjunction with a non-profit organization promoted in 1987 by the Costa Rican government, the Omar Dengo Foundation. In this country, a comprehensive management model is reported, covering the operational framework, infrastructure, monitoring and evaluation (Muñoz, et al., 2013).

In addition to Costa Rica, Uruguay is one of the few countries in the region that has an evaluation program for its social and technological inclusion plan (Plan Ceibal), which includes quantitative and qualitative approaches. However, this program has been repeatedly pointed out to the lack of articulation with the formal education system, being developed without the participation of educational authorities or teachers (Vaillant, 2013). This is a case in which political aspects have a strong influence on the development of programs. In Mexico, educational innovation programs are also strongly linked to changes in public administration and have a strong political component. Current models in Mexico include computer labs, educational portals and digital content, the provision of computer equipment to classrooms and the emergence of the 1 to 1 approach (Díaz Barriga Arceo, 2013).

In general, from the aforementioned strategic programs it can be observed that, even though ICT employment for education and innovation has appeared on the Latin American political agenda, it is not clear that they are accompanied by a theoretical support that strengthens its employment at classroom level and benefits its effective appropriation by the community members in which them seeks to influence. The strategies used vary from connectivity improvement, equipment provision and teachers training; to external participation proposals with financing purposes. On the other hand, there is no evidence of the development of an integrated management system in schools, one which includes the systematic information collection that allows its evaluation, as well as a precise definition of evaluation criteria.

\section{Discussion}

Literature shows that, although Latin American countries are formalizing strategic plans on ICT, most of them do not incorporate evaluation systems on their implementation (Cifuentes \& Vanderlinde, 2015) nor sistematic data collection. This is a characteristic that differentiates the region as well as the remarkable social and economic differences found. 
However, it can be seen how innovation through ICT has opened its way in the regional political agenda and the existence of a gradual progress in the areas of infrastructure and access.

For Casassus (2000) there is a problem of divergence of objectives in the management, from the scale perspective. Thus, politics is located at the macro level and deals with the economy from a pragmatic and neoliberal perspective; while the micro level is devoted to student learning, from pedagogy. The tensions originated are observable when the design of policies does not consider elements to articulate them. That is why considering the incorporation of ICT as regular part of educational management allows an association between technological innovation and the culture of the organization, an articulation that is yet lacking in the implementation of those policies. This work we has recovered multiple existing regional initiatives and some of the difficulties they face from the dimensions of context, policy and theoretical foundation. It also presents the need to approach the phenomenon from a systemic position that combines the communication of the discourse within the organization with its substantive processes.

\section{References}

Balarín, M. (2013). Las políticas TIC en los sistemas educativos de América Latina: caso Perú. Buenos Aires: UNICEF.

Ball, S., Maguire, M., \& Braun, A. (2012). How schools do policy: policy enactments in secondary schools. Londres: Routledge.

Casassus, J. (2000). Problemas de la gestión educativa en América Latina ( la tensión entre los paradigmas de tipo A y el tipo B). Santiago de Chile: UNESCO.

Chong , I. (2007). Métodos y técnicas de la investigación documental. In F. d. Letras, Investigación y Docencia en Bibliotecología (pp. 183-201). Ciudad de México: UNAM.

Cifuentes, G. (2016). Conceptualizando prácticas de liderazgo de las TIC: un estudio en la Educación Superior Colombiana. Archivos Analíticos de Políticas Educativas, 24(100), 1-15. doi:http://dx.doi.org/10.14507/epaa.24.2535

Cifuentes, G. (2016). Educational governance and innovation: Technology as end and means of government. Policy Futures in Education, 14(2), 286-299.

Cifuentes, G., \& Valbuena, M. (2018). El problema de la traducción de la política TIC: aportes para superar una racionalidad técnica. Archivos analíticos de Políticas Educativas, 26(120), 1-27.

Cifuentes, G., \& Vanderlinde, R. (2015). Liderazgo de las TIC en educación superior: estudio de caso múltiple en Colombia. Comunicar, 23(45), 133-142.

Díaz Barriga Arceo, F. (2013). Las políticas TIC en los sistemas educativos de América Latina: Caso México . Buenos Aires: UNICEF. 
Galvis Panqueva, Á. H. (2014). Las políticas TIC en los sistemas educativos de América Latina: caso Colombia. Buenos Aires: UNICEF.

Kozma, R. B. (2010). ICT Policies and Educational Transformation. UNESCO. From http://www.unesco.org/new/fileadmin/MULTIMEDIA/HQ/ED/ICT/pdf/ICTpoliedtran.pdf

López de Mesa, C. P. (2011). Políticas públicas y TIC en la educación. Revista Iberoamericana de Ciencia, Tecnología y Sociedad, 1-18.

Lugo, M. T., \& Brito, A. (2015). Las Políticas TIC en la educación de América Latina. Una oportunidad para saldar deudas pendientes. Archivos de Ciencias de la Educación(9), 1-16. Retrieved from http://www.archivosdeciencias.fahce.unlp.edu.ar/article/view/Archivos09a03

Muñoz, L., Brenes, M., Bujanda, M. E., Mora, M., Núñez, O., \& Zúñiga, M. (2013). Las políticas TIC en los sistemas educativos de América Latina: Caso Costa Rica . Buenos Aires: UNICEF.

Nuñez Urbina, A.A., Cabrera Mendoza, E., Ledezma Peralta, A.I., Moreno Reyes, H., Valdés Godínes, J.C., \& Lugo García, A.A. (2013). Apropiación social de las TIC y políticas educativas en la educación superior tecnológica. Pistas Educativas, 6-16.

OECD. (2004). Innovation in the Knowledge Economy: Implications for Education and Learning. Paris: OECD Publishing. doi:https://doi.org/10.1787/9789264105621-en

OECD. (2012). OECD Science, Technology and Industry Outlook 2012 . Paris.

Prashant , P., Naveed , B., \& Hamid , N. (2015). ICT Policies in developing countries: an evaluation with the extended design-actuality gaps framework. The Electronic Journal of Information Systems in Developing Countries, 71(1), 1-34.

Represas, N. F. (2015). Política Educativa de la UNESCO: reflexiones desde un modelo de análisis supranacional. Bordon. Revista de Pedagogía., 67(2). doi:DOI: 10.13042/Bordon.2015.67207

Salinas, J. (2005). La gestión de los entornos virtuales de formación. Seminario Internacional: La calidad de la formación en red en el Espacio Europeo de Educación Superior, (pp. 1-21). Tarragona.

SITEAL. (2019). SITEAL/TIC Indicadores. Retrieved from Sistema de Información de Tendencias Educativas en América Latina: http://www.tic.siteal.iipe.unesco.org/indicadores/consulta?indicador=701

Sunkel, G., Trucco, D., \& Espejo, A. (2013). La integración de tecnologías digitales en las escuelas de América Latina y el Caribe. Santiago de Chile: Naciones Unidas CEPAL.

Torres Velandía, S. Á., Barona Ríos, C., \& García Ponce de León, O. (2010). Infraestructura tecnológica y apropiación de las TIC en la Universidad Autónoma del Estado de Morelos. Perfiles Educativos, 32(127), 105-127.

UNESCO. (2011). Transforming Education: The Power of ICT Policies. Paris.

Vacchieri, A. (2013). Las políticas TIC en los sistemas educativos de América Latina: caso Argentina. Buenos Aires: UNICEF. 
Vaillant, D. (2013). Las políticas TIC en los sistemas educativos de América Latina: caso Uruguay. Buenos Aires: UNICEF.

Watson, D. (2006). Understanding the relationship between ICT and education means exploring innovation and change. Education and Information Technologies, 199-216. doi:DOI 10.1007/s10639-006-9016-2 